\title{
Courting Social Science: Chesler, Sanders, and Kalmuss
}

Peter W. Sperlich

Mark A. Chesler, Joseph Sanders, \& Debra S. Kalmuss, Social Science in Court: Mobilizing Experts in the School Desegregation Cases. Madison: University of Wisconsin Press, 1988. Pp. 286. $\$ 45.00$ cloth; $\$ 17.50$ paper.

This book reports the findings of a joined study of school desegregation litigation and expert testimony. The blend is interesting and productive and has been found in some earlier inquiries, such as Eleanor P. Wolf's splendid Trial and Error: The Detroit School Segregation Case' and I. A. Newby's polemical Challenge to the Court: Social Scientists and the Defense of Segregation, 1954-1966.2 The approach taken in the present volume differs from the earlier writings. Social Science in Court makes a distinct and important contribution to the literature on social science in litigation. Wolf was concerned primarily with the courts' reasoning about law and evidence, and Newby with the ideological inclinations of the experts. Chesler, Sanders, and Kalmuss, in contrast, give major attention to the organizational and strategic aspects of presenting social science evidence in litigation. ${ }^{3}$

Peter W. Sperlich is a professor of political science at the University of California at Berkeley. Ph.D. 1966, University of Michigan, Ann Arbor.

1. Detroit: Wayne State University Press, 1981 ("Wolf, Trial and Error").

2. Baton Rouge: Louisiana State University Press, 1969 ("Newby, Challenge to the Court").

3. For present purposes, "social science" includes psychology. Most of the early expert testimony in support of desegregation was provided by psychologists, such as Professor Kenneth Clark. 
Our focus . . . is upon the mobilization of a key evidentiary resource in the school desegregation cases, social science evidence and the expert witnesses needed to present it in court. We focus more on the mobilization of experts than on desegregation per se, and concentrate upon the problems social scientists and lawyers experienced. (At 4)

The primary data base of Social Science in Court consists of interviews with 69 attorneys, 67 social scientists, and 10 trial judges, drawn from 17 desegregation cases litigated after 1970. The cases are diverse in geography, legal issues, and scientific evidence. As the authors rightly note, the interviews "present a rich picture of courtroom life, of scholars' and attorneys' strategies, and of the problems in courtroom interaction encountered by the various parties" (at 5). To supplement the interviews, the authors examined the transcripts and other records of the 17 cases.

Wanting to shed light on the mobilization of social scientists and on the complex interactions of attorneys, judges, and experts, the authors also paid attention to the legal and political history of the desegregation movement. They were particularly interested in the plaintiffs' construction (after Brown $)^{4}$ of a new legal theory to support desegregation demands. This represented a shift from a private law to a public law model and encompassed a reorientation from equality of opportunity to equality of outcomes. The book does not include a systematic analysis of the constitutional and political implications of this change. The authors appear to be comfortable with the shift from protecting the rights of individuals to equalizing the social conditions of collectivities. ${ }^{5}$

Chesler, Sanders, and Kalmuss seem satisfied that a substantial amount of school desegregation has followed Brown. They do not systematically inquire into what arguably also are effects of the court-ordered remedies: white flight, the collapse of school discipline, and the widespread decline of educational standards. They do not ask whether alternative desegregation strategies might have imposed fewer costs on schools and communities. They do not raise the question whether-given that many inner-city schools have remained predominantly nonwhite-minority students might be better off by now if the reform movement had made quality education for all students rather than integrated schools its primary

4. Brown v. Board of Education, 347 U.S. 483 (1954).

5. The insistence on integration has reached remarkable levels in some areas of public life. The principle of the mandatory association of all peoples has produced laws that, for example, force landlords and innkeepers to rent to families with infants-denying to older people the right to be free of the noise and destruction that accompany small children. Regarding the issue at hand, the equality-of-outcome standard now has been applied in the public schools to such matters as disciplinary measures, grades, and promotions-which now must be roughly equal even for the most different groups. 
objective. Nor do they examine the question whether equality-of-outcomes strategies are likely to produce reverse discrimination.

The plaintiffs, it might be noted, achieved their greatest success in urging the adoption of the public law (equality-of-outcomes) model in the Detroit school desegregation case-Bradley थ. Milliken. ${ }^{6}$ Judge Roth, who initially had great reservations about the public law approach, was persuaded to adopt it and, thus, accept as relevant the social science testimony about "the effect of governmental policies on housing segregation, the relationship between school segregation and housing segregation, and the harmful effects of segregation on black children" (at 210). Under the private law model, this evidence would not have been legally relevant since it did not regard and prove school board intention. Judge Roth "came as close as any judge to being persuaded to adopt a public law view of violation which would not require proof of specific, intentional segregative acts on the part of the school board" (at 210). Since the Detroit school board was thoroughly integrationist-indeed, it had received an award from the NAACP for its efforts-intentional school segregation clearly did not exist. The plaintiffs' success was due entirely to the court's adoption of the public law model. After finding liability, the court also embraced the cure advocated by the plaintiffs (and the school board defendant!): metropolitan busing. The U.S. Supreme Court overturned this remedy in Milliken ข. Bradley. ${ }^{7}$

While it can be and has been charged that the social science experts confused and misled Judge Roth, ${ }^{8}$ it is important to point out that this disservice became possible only after the attorneys had argued and the judge had accepted the legal theory which established the relevancy of this type of evidence. As always, science can enter the courtroom only upon the law's invitation, and it can influence litigation only within the framework set by the law.

II

The book is organized in three major parts, dealing respectively with

(1) The background of the desegregation movement and the choice to pursue desegregation through the courts, including a history of the legal arguments and social science evidence presented in court; (2) the processes and problems that lawyers and social scientists encountered in gathering and using social science resources in seventeen school

6. 338 F. Supp. 582 (E.D. Mich., 1971).

7. 418 U.S. 717 (1974). For a detailed analysis of the Detroit litigation see Wolf, Trial and Error.

8. Wolf, Trial and Error 85, 101, 108, 135, 229. 
desegregation cases; and (3) the consequences of using social scientists and social science for their disciplines, for the cases, and for the desegregation effort. (At 6)

The second and third parts contain the unique contributions of the investigation.

The first part reviews the organizational and strategic developments with the NAACP and the Legal Defense Fund. Of particular interest is the analysis of the choice of litigation as primary desegregation strategy and the decision to include social scientists and social science data in the litigation efforts.

The second part offers several chapters on the task of finding social science experts willing to be witnesses and of preparing them for their work. Considerable attention is given to the (unaccustomed) difficulties confronting scholars in the courtroom and to the strategies by which these problems might be overcome. There is an interesting discussion on the different perceptions of attorneys and scholars as to what makes a "good witness." Also included are discourses on expert-attorney interactions, normative discrepancies, role conflicts, and the cross-examination stress experienced by expert witnesses.

The third part examines the effects on the social scientists of providing expert testimony. It pays particular attention to the resulting professional and personal conflicts. It explores how the attorneys were affected by working with social science experts. Also included are considerations of the relative advantages of different ways of presenting expert testimony in court, especially of the advisability of using panels of court-appointed experts. Finally, there are two chapters evaluating the impact of social science evidence on the school desegregation cases and probing the limits of a national litigation strategy as a method for reforming local institutions.

\section{III}

School desegregation litigation began in the last decade of the 19th century with Plessy v. Ferguson ${ }^{9}$ and Cumming v. County Board of Education. ${ }^{10}$ It lacked success until Brown v. Board of Education. ${ }^{11}$ Not coincidentally, Brown also is the first case in which the plaintiffs presented substantial amounts of social science evidence-and of which the Court took notice: the famous footnote 11 . Social science evidence and expert testimony have had an important place in school desegregation suits ever since. At

9. 163 U.S. 537 (1896).

10. 175 U.S. 528 (1899).

11. 347 U.S. 483. 
first, expert assistance was provided almost exclusively to the plaintiffs. Later, the defendants also received help. ${ }^{12}$ Brown, in any case, opened a floodgate to desegregation litigation, as can be discerned from the drastic increase in the number of appellate cases: $1937-46=7 ; 1947-56=21$; $1957-66=151 ; 1967-76=$ about 1,$500 ; 1977-81=644$ (at 4 ).

The introduction of social science evidence and experts presented attorneys, judges, and scholars with significant and difficult problemswhich are far from being resolved in school desegregation or other types of litigation. The nature of the school desegregation litigation, the adversary style of the legal proceedings, and the traditions of academic scholarship contributed to the problems encountered in the cases under review.

Attorneys faced organizational (mobilization of experts), tactical (how best to use the experts), and strategic (how to combine legal theory and social science evidence) challenges. The experts had to make difficult choices about adopting

(a) a neutral versus a partisan value frame when electing to testify, interpreting evidence, and presenting evidence in court; (b) a teacher versus an advocate role when testifying in court; and (c) an academic role as the creator of knowledge versus a witness role as the applier of knowledge to specific problems or situations. (At 5)

The judges were confronted with the quandary of how to assure themselves that the expert testimony received was essentially unbiased and represented the best available evidence. They also had to determine to what degree they could and wanted to rely upon it in deciding the case and in constructing a remedy when liability was found.

Social Science in Court supplies a unique and valuable set of quantitative data about the scope and severity of the difficulties experienced by experts, attorneys, and judges. It also provides information about the various coping strategies and their relative success. These are some of the findings: Discrepancies between the norms of science and of law were expected by $96 \%$ and experienced by $90 \%$ of the scholars who served as

12. Newby's Challenge to the Court (cited in note 2) attacked the defendants' experts as "scientific racists." Other commentators have asserted that the defendants did not deserve expert assistance, and that to provide such assistance evinced (at minimum) a gross deficiency in scholarly judgment (Chesler et al. at 130-31). Ideological judgments as to who does and who does not deserve the benefits of scholarship are not limited to the domain of school desegregation. For example, when Rosalind Rosenberg testified that some differentiated employment patterns may be due to different job preference among men and women, feminist historians called her testimony an "immoral act" and the Conference Group on Women's History passed a resolution stating: "We believe as feminist scholars we have a responsibility not to allow our scholarship to be used against the interests of women struggling for equity in our society" (at 162). Ideologies fiercely held and interests strongly pursued are incompatible with the requirements of science. When scholars are captured by interest groups, the factual truth of observations must give way to "political correctness." 
experts (at 110). The "normative stance" taken by the expert importantly determined to what degree the discrepancies produced role conflicts. A plurality of the experts held on to a social science normative stance $(46 \%)$, a large group adopted a legal-adversary stance $(39 \%)$, and some took a mixed position (15\%). Whereas $62 \%$ of those experts in the social science and mixed groups experienced role conflict, only $25 \%$ of the legal-adversary group did (at 119). This is not particularly surprising. Adopting adversarial norms reduces, but retaining scientific norms increases, the stress and conflict of giving testimony in court. The majority of the experts, however, kept "a strong commitment to nonadversary social science values, regardless of their comfort in court" (at 120).

Almost all the experts interviewed by the authors provided testimony for, and were paid by, one of the parties to the litigation. Few were employed by the courts. This arrangement maximizes the pressure to adopt adversarial norms and to give a partisan shading to the testimony. One might expect plaintiff and defense experts to be converted at equal rates. This, however, was not the case. Whereas only $18 \%$ of the defense experts adopted legal-adversary norms, $53 \%$ of the plaintiff experts did (at 121). Clearly, the partisan pressure was greater on the plaintiffs' side.

The experts' field-social science or education-also had an effect. Only $24 \%$ of the social scientists, but $63 \%$ of the educationists, adopted adversarial norms. This is not surprising. The educationists belong to an applied field with a habit of active involvement in school affairs and educational policies. Maximum differentiation is reached when field and litigation party are combined. The adversarial figures range from a low of $13 \%$ (defense social scientists) through $35 \%$ (plaintiff social scientists) and $33 \%$ (defense educationists) to a high of $77 \%$ (plaintiff educationists). The last group, it seems, was inclined to an adversarial stance and least resisted partisan pressures. The lesson? Not all scholars giving testimony can be assumed to be committed to such scientific norms as neutrality and objectivity.

A scientist asked to provide expert testimony may find his own political beliefs and those of the party seeking his services are in conflict. He may also find that providing expert testimony for a particular litigant may meet with the stern disapproval from colleagues and university administrators. Such, indeed, was the case when scholars testified for the defense in school desegregation cases. Most scholars-including most defense experts $^{13}$ - traditionally have supported the principles of racial equality and desegregation (at 163). Not surprisingly, then, $68 \%$ of the defense experts

13. As Chesler et al. point out: "Many defense witnesses testified for the defense in spite of, rather than because of, their personal political position" (at 164). For them, clearly, personal preferences did not overwhelm scholarship. Their greater commitment to scholarly neutrality also can be glimpsed from the fact that $100 \%$ of the defense experts but only $60 \%$ of the plaintiff experts declared themselves willing to assist the other side (at 167). 
reported personal and professional conflict, but only $13 \%$ of the plaintiff experts did (at 164, 170). Professional conflict also was more prevalent among the social science experts $(61 \%)$ than among the education experts $(21 \%)$ (p. 172).

IV

If Social Science in Court has a fundamental weakness, it is the small numbers on which its findings are based. As noted earlier, the sample included 67 social scientists. When these are divided into plaintiff and defense witnesses, and (at the same time) into social scientists and educationists, the numerical foundations of the reported percentages become extremely weak. Clearly, the study needs replications with greatly expanded samples.

There are a number of small flaws in Social Science in Court. Some cases are inadequately identified. Nonstandard but "politically correct" English is widely employed. The authors also appear to be strangers to some basic statistical concepts. In writing about the problem of judicial distrust of expert testimony, engendered by the use of technical rather than ordinary terms, they write: "Physicians speak of contusions and abrasions instead of cuts and scratches . . . and social science experts speak of multiple regressions and correlations instead of cause and effect" (at 98). Regression and correlation, if this still needs to be pointed out, are techniques that identify statistical associations. They are not the same as cause-and-effect relationships.

These matters, however, are minor annoyances in what is otherwise a splendid pioneering effort. The book can be warmly recommended to scholars and attorneys alike. 